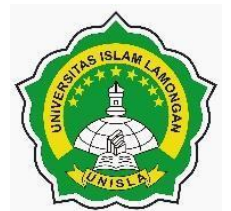

\title{
The Effect of Feeding Acidifier and Probiotics with Different Levels in The Diet Growth on Broiler Performance
}

\author{
Fita Ridhana a, Rahmawati a, Ali Makmur b \\ a Faculty of Agriculture, Universitas Gajah Putih, Takengon Aceh Tengah, Indonesia \\ ${ }^{b}$ Faculty of Agriculture, Universitas Syiah Kuala, Blang Kejeren, Gayo Lues, Indonesia \\ email:anfitaridhana12@gmail.com,bali_pdsku@unsyiah.ac.id,rahmawatiugp@gmail.com
}

\section{ART ICLE INFO \\ Article history: \\ Received 14 December 2020 \\ Revised 22 December 2020 \\ Accepted 01 Nopember 2021 \\ Available online 08 Nopember \\ 2021}

\section{Keywords:}

Broiler,

Probiotic,

Acidifier,

Growth

\begin{abstract}
A B S T R A C T
This research which aims to determine the effect of probiotic and Acidifier supplementations in the fermentation diet on growth of broiler has done in Takengon, Central Aceh District from August until October 2020. This research used 160 chicks strain Cobb 89 produced by PT. Charoen Pokphand. This study used a complete randomized design consisting of 4 treatments and 4 replications. The treatment of probiotic and Acidifier supplementations were: $0 \%$ (A), $0.1 \%$ (B), $0.2 \%(C), 0.3 \%(D)$. Parameters observed were achievement of final weight, weight gain, feed consumption, feed conversion, and feed efficiency. Data was analyzed by analysis of variance (ANOVA) and continued by Duncan Multiple Range Test if significant effect was detected. The result showed that the differences in supplementation of probiotic and Acidifiers effected significantly $(\mathrm{P}<0.05)$ on the final weight, weight gain, feed conversion and feed efficiency. However, there was no significant effect on rate of consumption. The result of present study showed that the combination of probiotic and Acidifier had a best impact on broiler growth and it was also decreased mortality of chicken.
\end{abstract}

\author{
IEEE style in citing this \\ article: \\ F. Ridhana Rahmawati and A. \\ Makmur, "The Effect of \\ Feeding Acidifier and Probiotics \\ with Different Levels in The \\ Diet Growth on Broiler \\ Performance ," Jurnal Ternak, \\ vol. 12 , no. 2 , pp. $28-35,2021$
}

Jurnal Ternak (Animal Science Journal) Faculty of Animal science - Lamongan Islamic University) with CC BY NC SA license.

\section{Introduction}

Public demand for animal protein is increasing every year as broiler chickens are the most efficient livestock to produce meat because genetically broiler chickens grow faster than other chickens [1]. In general, broiler chickens at the age of 5 - 6 weeks can reach a body weight of 1.5 - 1.9 $\mathrm{kg}$. The main problem in increasing livestock production, including broiler chickens, is low feed efficiency, and the digestive tract metabolic system disruption due to the presence of pathogenic microorganisms such as Escherichia Coli and Salmonella sp. which inhibit the growth process and interfere with health. Acidifier is an acid that is included in the feed to lower the $\mathrm{pH}$ of the intestine so that it inhibits the growth of pathogenic intestinal microflora. Inhibition of the growth of pathogenic intestinal microflora serves to reduce pathogenic intestinal microflora competing for nutrients so that better results are obtained in the growth and performance of chickens [2]. The acidifier can be citric acid, lactic acid, propionic acid, acetic acid or a mixture of organic acids. The acidifier creates an acidic environment in the small intestine, resulting in ideal conditions for the growth of Lactobacillus $s p$. and other non-pathogenic microbes and inhibit the development of Escherichia coli, Salmonella and other pathogenic microbes. The performance of an acidifier in the small intestine will support the activity and function of digestive enzymes [3]. Based on the problems above, it is necessary to use feed additives in feed that can stimulate production, increase feed digestibility and improve broiler metabolism, one 
of which is by utilizing probiotics and acidifiers. The use of a combination of probiotic supplementation and acidifier is able to streamline the use of feed, improve metabolism and increase production which will affect the growth of broiler chickens. The purpose of this study was to determine the effect of adding supplementation acidifier and probiotic in feed to increase growth and performance of broiler chickens and to determine the optimal percentage of the most appropriate combination of acidifier and probiotic in feed.

\section{Method}

Stages

The research materials used in this study were 160 DOC broilers of the Cobb 89 strain. The study was carried out for 55 days, preparation for 20 days and chicken rearing for 35 days.



Figure 1. Production of fermented feed

Table 1. Nutritional composition of fermented ration

Substances

Dietary Fermented ration*

$\begin{array}{lc}\text { Dry } & 88.87 \\ \text { matter \% Protein \% } & 14.46 \\ \text { Fat \% } & 6.5 \\ \text { Crude fiber \% } & 9.75 \\ \text { Ash \% } & 2.25\end{array}$

*Results of the Nutrition Lab analysis and fodder at Syiah Kuala University

Place and Time

Research was carried out in Takengon, Central Aceh District for 55 days. The first stage was for 20 days of cage preparation, research tools and materials. The second stage was the maintenance of broiler chickens for 35 days and the collection of research data. This research had been conducted from August-October 2020.

Type and Design

The research design used was a completely randomized design (CRD) with 4 treatments using an acidifier and probiotics. There were 4 treatments and each treatment was repeated 4 times. Each experimental group consisted of 10 chickens for a total of 160 chickens. The research chart is in Table 2. 
Table 2. Chart of treatment in re-study

\begin{tabular}{ccccc}
\hline \multirow{2}{*}{$(\mathrm{n})$} & \multicolumn{4}{c}{ Percentage of Acidifier+ Probiotic } \\
\cline { 2 - 5 } & $\mathrm{A}=0 \%$ & $\mathrm{~B}=0.1 \%$ & $\mathrm{C}=0.2 \%$ & $\mathrm{D}=0.3 \%$ \\
\hline 1 & $\mathrm{~A} 1$ & $\mathrm{~B} 1$ & $\mathrm{C} 1$ & $\mathrm{D} 1$ \\
3 & $\mathrm{~A} 2$ & $\mathrm{~B} 2$ & $\mathrm{C} 2$ & $\mathrm{D} 2$ \\
4 & $\mathrm{~A} 3$ & $\mathrm{~B} 3$ & $\mathrm{C} 3$ & $\mathrm{D} 3$ \\
\hline Total & $\mathrm{A} 4$ & $\mathrm{~B} 4$ & $\mathrm{C} 4$ & $\mathrm{D} 4$ \\
\hline
\end{tabular}

Information:

A, B, C, D = Research feed treatment

$1-4 \quad=$ Research

$0 \%-0.3 \%=$ Fermented feeding treatment

A1-D4 = Experimental unit

Treatment of the use of Acidifier and probiotics with the Protamide brand with different levels as shown in Table 3:

Table 3. Research ration composition (\%)

\begin{tabular}{clcccc}
\hline \multirow{2}{*}{ No } & \multicolumn{4}{c}{ Ingredients Research Ration Composition $(\%)$} \\
\cline { 3 - 6 } & & A & B & C & D \\
\cline { 3 - 5 } & & $($ control $)$ & $(0.1 \%)$ & $(0.2 \%)$ & $(0.3 \%)$ \\
\hline 1 & Commercial Feed ${ }^{* *}$ & 90 & 89.9 & 89.8 & 89.7 \\
2 & Fermented Feed & 10 & 10 & 10 & 10 \\
3 & Acidifier & 0 & 0.05 & 0.10 & 0.15 \\
4 & Protamide & 0 & 0.05 & 0.10 & 0.15 \\
\hline \multirow{2}{*}{$\begin{array}{l}\text { Total } \\
\end{array}$} & Coarse Fiber & 100 & 100 & 100 & 100 \\
& Protein & 5,475 & 5.47 & 5,465 & 5.46 \\
& Fat & 21.24 & 21.22 & 21.20 & 21.18 \\
& Ash & 5.1455 .135 & 5.14 & 5.145 & 5.15 \\
& 6.52 & 6.515 & 6.51 & 6.50
\end{tabular}

*Calculation based on calculation

** Commercial Feed (N511 Production of Charoen Pokphan)

Description:

A: The ration without supplementation protamide + acidifiers (ration control)

B: Rations with supplementation protamide + acidifiers (50:50) $0.1 \%$ 
C: Rations with supplementation protamide + acidifiers (50:50) $0.2 \%$

D : Rations with supplementation protamide + acidifiers (50:50) $0.3 \%$

Parameters

Final body weight data was obtained from weighing the weight of the chickens in the fifth week (end of the study) which included (1) Weight gain (grams): body weight gain data was obtained by weighing every week which is the difference between final body weight weighing and weighing the initial body weight unit time (grams/week).PBB = Final body weight (grams) - Initial body weight (grams) (2) Feed Consumption (grams): feed consumption data obtained by weighing the feed given for one week, then reduced by weighing the remaining feed for one week. Feed Consumption (grams) $=$ Total Feed (grams) - Leftover Feed (grams) (3) Feed Conversion: feed conversion is calculated based on the ratio of the amount of feed consumed with the increase in body weight resulting from feeding the feed in the same time and unit. (4) Feed efficiency (\%): Feed efficiency is the ratio between body weight growth and feed consumption.

Data Analysis

Data from this study were analyzed using analysis of variance (ANOVA) to determine the effect of treatment on the observed parameters. If the ANOVA analysis showed significantly different results, then continued with Duncan's test.

\section{Results and Discussion}

\section{Final Body}

Body weight is the body weight of chickens aged 35 days before slaughter and after fasting for \pm 12 hours [4]. Body weight gain is one of the parameters that is often observed to assess the success or desired level of production development. Final body weight was calculated at the end of the study, i.e. at week 5 . The average final body weight and weight gain of broiler chickens can be seen in Table 4 . Table 4. Average final body weight and weight gain (PBB) of broiler chickens for 5 weeks.

Variables

Treatment
A $(0 \%)$
B $(0.1 \%)$
$\mathrm{C}(0.2 \%)$
$\mathrm{D}(0.3 \%)$

Final Body Weight (gr/head)

$1928.92( \pm 44.50)^{\mathrm{a}} \quad 2013,73( \pm 56.23)^{\mathrm{a}} \quad 1966.11( \pm 45.65)^{\mathrm{a}} \quad 2155.68( \pm 67.29)^{\mathrm{b}}$

Weight(gr/head/week)

$$
378.30( \pm 14.05)^{\mathrm{a}} \quad 395.24( \pm 18.06)^{\mathrm{a}} \quad 388.87( \pm 13.55)^{\mathrm{a}} \quad 423.40( \pm 18.78)^{\mathrm{b}}
$$

Information: ${ }^{\mathrm{a}, \mathrm{b}}$ Different superscripts showed significant differences $(\mathrm{P}<0.05)$.

Based on Table 4, it can be seen that the lowest final weight was found in treatment A (feed without treatment) which was $1928.92 \mathrm{~g} /$ head, while the highest final weight was found in treatment D (supplementation of probiotics and acidifier $0.3 \%$ ) which was $2155,68 \mathrm{~g} / \mathrm{head}$.

The provision of protamide and probiotic supplementation acidifier in the ration showed a statistically significant difference $(\mathrm{P}<0.05)$ on the final body weight of broiler chickens. Increased body weight of broiler chickens is a positive effect of an acidifier, controlling the balance of the digestive tract microflora, stimulating the performance of digestive tract enzymes, increasing feed digestibility and the appearance of poultry production [5]. [6] stated that Acidifier (organic acid) functions to increase digestibility in the body by increasing the performance of digestive enzymes, thereby causing an acidic sensation that lowers the $\mathrm{pH}$ in the intestines to maintain the balance of microbes in the digestive tract and can suppress pathogenic bacteria that cause the intestines to be healthy. [7] stated 
that the addition of an ideal acidifier to improve performance concluded from several studies was less than $0.5 \%$. In general, the ideal dose of using acidifier commercial product ranges from $0.2 \%$ to $1 \%$ of feed which has an impact on the significant improvement of broiler growth in rearing up to 35 days of age. This is in line [3] which states that the use of organic in broilers can increase body weight and chickens become healthy.

\section{Weight}

Weight gain is a change in size that includes changes in live weight and body composition. Body weight gain can be calculated every week based on the final body weight minus the previous body weight in grams/head/week. In Table 4, it can be seen that the difference in the highest weight gain of broiler chickens was found in treatment D (0.3\% probiotic and acidifier), which was 423.40 grams/week/head and followed by treatment B (0.1 probiotic and acidifier) which was 395, 24 grams/week/head, and C (0.2\% probiotic and acidifier) was 388.87 grams/week/head. The lowest weight gain was obtained in broiler chickens with treatment A (without supplementation) which was 378.30 grams/week/head. The difference in final body weight of broiler chickens was found in $5 \%$ fermented coffee skin flour feed and probiotic with an average of $847,5 \mathrm{gram} / \mathrm{head}$ [8]. The increase in body weight of broilers with $0.3 \%$ supplementation of probiotics and acidifiers is caused by the function of from an acidifier that maintains microbial balance in the digestive tract system by maintaining the $\mathrm{pH}$ of the digestive tract thereby increasing absorption from the food consumed [9]. In addition, [6] stated that Acidifier (organic acid) functions to increase digestibility in the body by increasing the performance of digestive enzymes, thereby causing an acidic sensation that lowers the $\mathrm{pH}$ in the intestines to maintain the balance of microbes in the digestive tract and can suppress pathogenic bacteria that cause the intestines to be healthy. The advantage of adding probiotics to feed can maintain the balance of microflora in the digestive tract, improve intestinal health and ultimately improve performance [5].

\section{Feed Consumption}

Consumption of broiler feed depends on strain, age, activity and environmental temperature. Feed consumption can be calculated by reducing the amount of feed given to the rest and wasted feed [10]. The average feed consumption, feed conversion and feed efficiency can be seen in Table 5 .

Table 5. Average feed consumption, conversion and feed efficiency of broiler chickens per week.

Treatment

Variables

$\mathrm{A}(0 \%) \quad \mathrm{B}(0.1 \%) \quad \mathrm{C}(0.2 \%) \quad \mathrm{D}(0.3 \%)$

Feed consumption (gr/week/head)

$618.26( \pm 13.86) \quad 631.70( \pm 11.23) \quad 614.33( \pm 8.23) \quad 634.56( \pm 7.43)$

Feed conversion (gr/week/head)

$$
1.63( \pm 0.13)^{\mathrm{a}} \quad 1.60( \pm 0.23)^{\mathrm{a}} \quad 1.59( \pm 0.25)^{\mathrm{a}} \quad 1.50( \pm 0.18)^{\mathrm{b}}
$$

Feed Efficiency (gr/week/head)

$$
61( \pm 2.03)^{\mathrm{a}} \quad 63( \pm 3.15)^{\mathrm{a}} \quad 63( \pm 2.83)^{\mathrm{a}} \quad 67( \pm 1.63)^{\mathrm{b}}
$$

Information: ${ }^{\mathrm{a}, \mathrm{b}}$ Different superscripts showed significant differences $(\mathrm{P}<0.05)$.

The lowest average ration consumption was found in treatment $\mathrm{C}(0.2 \%$ probiotic acidifier supplementation) which was $614.33 \mathrm{grams} / \mathrm{head} /$ week, while the highest ration consumption was found in D treatment (feed with probiotic supplementation and acidifier treatment $0.3 \%$ ) namely of 634.56 grams/head/week. Although there was no significant difference in the consumption of rations, 
the application of organic acid (acidifier) into the feed tended to reduce the amount of consumption. Some additions of feed additives have no effect on feed consumtion such us the addition of dayak onion extract to the performance of broiler [10] The decrease in ration consumption is thought to have two causes. The first cause is due to the mechanism of several functions of probiotics (lactic acid bacteria) improving the digestive tract and stimulating the production of enzymes to digest rations, which causes the digestive process in the intestines to become better [12]. This is suspected that the food consumed will stay longer in the intestine or the rate of the ration becomes slower so that the consequence is the consumption of the chicken ration will decrease. The second cause is the pungent sour taste due to the low $\mathrm{pH}$ of the ration so that it reduces palatability. [5] stated that the addition of organic acids in feed can reduce palatability so that consumption is reduced. In line with [13] stated that the addition of an acidifier 1.2\%/100 grams that had a significant effect $(\mathrm{P}<0.05)$ in reducing feed consumption.[14] states that the factors that affects feed consumption in broiler chickens are feed quality such as metabolic energy, protein intake and amino acid balance that must be in accordance with livestock needs. Giving organic acids (acidifier) into the feed tends to reduce the amount of consumption.

\section{Conversion of Feed}

Conversion of ration is the amount of food consumed by a chicken in a certain period of time to achieve optimal shape and weight. Feed conversion is the main benchmark to show the success or failure of a given feed used by the livestock body, according to [15] stating that if the ration conversion is small, it means that the chicken body weight gain is satisfactory or the chicken eats efficiently.

Based on table 5 above, the lowest average ration conversion was found in treatment $\mathrm{D}$ (supplementation of probiotics and acidifier $0.3 \%$ ) which was 1.50, while the highest ration conversion was found in treatment A (feed without treatment) which was 1.63. Acidifier is able to increase body weight along with increasing levels, but it also significantly improves feed conversion [16]. The ration conversion in this study is still considered normal, [10] states that a good ration conversion range from 1.75 to 2.00 . [17] stated that the higher the feed conversion value, the more feed needed to increase body weight.

The feed conversion value is influenced by several factors including genetics, type of feed used, feed additive used in feed, maintenance management, and environmental temperature [18]. The smaller the ration conversion rate means the more efficient farmers use the cost of rations and the higher the profit obtained or vice versa, a small ration conversion rate means the number of rations used to produce one kilogram of meat is getting less [19].

\section{The Feed Efficiency}

The results of the analysis of variance on the treatment of probiotic and acidifier supplementation in fermented rations showed differences in the level of efficiency of broiler rations. Based on Table 5, the lowest average ration efficiency was found in treatment A (without probiotic and supplementation acidifier) which was $61 \%$, while the highest ration efficiency was found in treatment D (probiotic and supplementation acidifier $0.3 \%$ ) which was $67 \%$. the addition of an acidifier $1.2 \% / 100$ grams significantly $(\mathrm{P}<0.05)$ increased body weight and ration efficiency [13].

The results showed that the higher the probiotic and acidifier supplementation in the given fermented ration, the higher the efficiency value of the ration. This is because the function of acidifiers and probiotics in the digestive tract controls the balance of the microflora of the digestive tract, stimulates the performance of digestive enzymes, and increases feed digestibility [20]. This is related to the ration conversion, the greater the ration conversion value, the smaller the efficiency value and conversely the smaller the ration conversion value, the greater the efficiency value. The efficiency of the use of rations is influenced by consumption and body weight gain, if minimum feed consumption results in body weight gain, it means that the efficiency of feed use is high [21]. 


\section{Conclusions}

The use of probiotic and supplementation acidifier in feed on the growth of broilers can be concluded that the use of a combination of probiotics and acidifiers up to a level of $0.3 \%$ can increase broiler growth, weight gain and feed efficiency. Supplementation with probiotics and acidifiers does not increase feed consumption so that it is very beneficial for farmers. The use of probiotics and acidifiers is recommended at the level of $0.3 \%$ to meet the needs and increase body weight in broilers.

\section{References}

[1] Shen, X., and Yi, Xueqin Ni, D. Zeng, B. Jing M. Lei, Z. Bian, y. Zeng Tao Li and J. Xin. 2014. Effect of Lactobacillus plantarum on Productions Performance, Immune Characteristics, Antioxidant Status and Intestinal Microflora or bursin Ummunized Broiler, Canadian Journal of Microbology Vo. 60. No 4:193-202.

[2] Lestariningsih, O. Sjofjan, E. Sudjarwo. 2015. The Effect of Meniran Plant Flour (Phyllanthus niruri Linn) as a Feed Additive to the Small Intestine Microflora of Broilers. J. Agrippet 15(2):8589.

[3] Kopecky J., C. Hencar., J Weis. 2012. Effect of organic acids supplement on performance of broiler chickens. J Anim Sci Biotech 45(1): 51-54.

[4] Widyaningsih, I. 2008. Comparative Study of Nutrient Agar Media with Snakehead Fish Filtrate Supplement for Detection of Mycobacterium tuberculosis compared to Lowenstein's Media. Faculty of Medicine, Wijaya Kusuma University Surabaya Comparative Study of Nutrient Media.

[5] Saputra, WY, N. Suthama and LD Mahfudz. 2013. Giving a combination of double step down feed and citric acid as an effort to increase the efficiency of broiler farming business. J. Nutrition and Animal Feed Bulletin. 10(1) : 34-40.

[6] Hasanuddin. SVD 2013. Meat fat and cholesterol in broiler chickens fed step down protein feed with the addition of lime juice as an acidifier. Bulletin of Nutrition and Animal Feed. 9(1) : 4753.

[7] Eidelsburger and M.Kirchgessner. 1992. Influence of formic acid, calcium formiate and sodium hydrogencarbonate on daily weight gain, feed intake, feed conversion rate and digestibility, 7: Investigations about the nutritive efficacy of organic acids in the rearing of piglets. Technische Univ. Munich, Freising, Germany.

[8] F. Ridhana, I. Fitri. 2019. Peningkatan Persentase Bobot Karkas Ayam Lokal Pedaging dengan Pemberian Pakan fermentasi Tepung Kulit Kopi Gayo dan Probiotik di Kabupaten Aceh Tengah. J. Ternak. Vol 10 (2) :33-39

[9] Roth, FX, M. Kirchgessener. 2003. The role of formic acid in animal nutrition. Institute for Animal Nutrition and Physiology. Technical University of Munich. Munich.

[10] Amrullah, IK 2003. Nutrition of Layer Chickens. One Mount Budi. Bogor.

[11] Zakiyatulyaqin., Setiawan, D. Purnomosidi, M. 2020. The Performance of Broiler Chickens with The Addition of Dayak onion extract in Drinking Water. J. Ternak. Vol 11(2) : 91-96.

[12] Seifert, HSH and F. Gessler. 1997. Continuous oral application of probiotic B. Cereus an alternative to the prevention of enteroxia. Animal Research and Development. 46:30-38. 
\{13] Huda, S. LD. Mahfudz, S. Kusmiati. 2019. Effect of Step Down Protein and Addition of Acidifier to Feed on Broiler Chicken Performance. J. Animal Science. 14(4):404-410

[14] National Research Council. 1994. Nutrient Requirements of Poultry. 9th resid edition. National Academic Press, Washington, DC.

[15] Rasyaf, 2006. Breeding broilers. Self-help spreader, Jakarta.

[16] Salgado-Tránsito, L., JC Del-Río-García, JL Arjona-Román, E. Moreno-Martínez, A. MéndezAlbores. 2011. Effect of citric acid supplemented diets on aflatoxin degradation, growth performance and serum parameters in broiler chickens. Arc. Med. Vet. 43: 215-222.

[17] Saepulmillah, A. 2010. Performance of Broiler Chickens on Commercial Feed and Vegetable Feed with Addition of Dysapro. Department of Animal Production and Technology, Faculty of Animal Husbandry, Bogor Agricultural University, Bogor. (Essay).

[18] James, RG 2009. Modern livestock and poultry production. 7th Ed. Thomson Delmar Learning Inc., FFA Activities, London.

[19] Fadilah, R., A. Polana., S. Alam and E. Purwanto. 2007. Successful Broiler Chicken Breeding. First Print. PT Agromedia Pustaka, Jakarta.

[20] Natsir, MH. 2005. Effect of using encapsulated on encapsulated lactic acid as an acidifier on protein digestibility and metabolic energy of broilers. J Tropical Livestock 6(2): 13-17.

[21] Widjiastuti and E. Sujana. (2009). Utilization of Bread Waste Flour in Broiler Chicken Ration and Its Implications on Ration Efficiency as well. National Seminar on the Unpad Faculty of Animal Husbandry Development of Production Systems and Utilization of Local Resources for Self-Sufficiency in Animal-Originated Foods. Padjadjaran University. 